\title{
Conceptions and Perceptions Pre-service Teachers on the Use of Paradidactic Books in Chemistry Teaching
}

\author{
Débora Luana Kurz@ $\oplus^{a}$ \\ Lucilene Piva ${ }^{\mathrm{a}}$ \\ Everton Bedin $\odot^{a}$
}

a Programa de Pós-Graduação em Ensino de Ciências e Matemática, Universidade Luterana do Brasil, Canoas, RS, Brasil.

Received for publication on 21 May 2019. Accepted, after revision, on 2 Aug. 2019.

Assigned editor: Renato P. dos Santos.

\begin{abstract}
This research aimed to investigate the conception of chemistry pre-service teachers in the use of para-didactic books in the teaching of Chemistry, with emphasis on questions related to learning mechanisms, didactic strategies and discussion in the classroom. In the methodology, a questionnaire structured in two axes was used as a data collection instrument, which was made available to students of the Chemistry course of a community university in Canoas, metropolitan region of Porto Alegre/RS. This questionnaire, as an empirical part of this article, was analyzed in the light of Bardin's Content Analysis (2011), and its qualitative and quantitative data are expressed through figures and tables. In the data representation, after analysis and interpretation, through the conceptions of the undergraduate students, the importance of the use of this resource in pedagogical practices was verified, corroborating, in addition to the teaching and learning processes, with the improvement of teaching and, mainly, with the contextualization of scientific knowledge in the light of the socio-cultural knowledge of the student. Thus, based on the paradigmatic book, advances in school actions are expected to build and experience a new contextualized and meaningful narrative to the student, also contributing to the way of teaching and learning of the different teachers, providing them with a tool that has the scientific, epistemological and social foundation.
\end{abstract}

Keywords: Chemistry teaching; Paradidactic books; Teaching proposal.

\section{Concepções e Percepções de Licenciandos acerca da Utilização de Livros Paradidáticos no Ensino de Química}

\section{RESUMO}

Esta pesquisa visou investigar a concepção de licenciandos do curso de Química acerca da utilização de livros paradidáticos no ensino de Química, dando-se ênfase a questões referentes aos mecanismos de aprendizagem, estratégias didáticas e discussão em sala de aula. Na metodologia, utilizou-se, como instrumento de coleta de dados, um questionário estruturado em dois eixos, o qual foi disponibilizado para os estudantes do curso de Química de uma universidade comunitária de Canoas, região metropolitana de Porto Alegre/RS. Este questionário, como parte empírica deste

Corresponding author: Débora Luana Kurz. E-mail: kurz.deboraluana@gmail.com

Vol. 21

N. 5

p. $62-80$

Sep./Oct. 2019 
artigo, foi analisado à luz da Análise de Conteúdos de Bardin (2011), sendo seus dados, de forma quali-quantitativa, expressos por meio de figuras e tabelas. Na representação dos dados, após análise e interpretação, percebeu-se, por meio das concepções dos licenciandos, a importância da utilização deste recurso nas práticas pedagógicas, corroborando, para além dos processos de ensino e de aprendizagem, com o aperfeiçoamento docente e, principalmente, com a contextualização dos saberes científicos à luz do saber sociocultural do aluno. Desta forma, com base no livro paradidático, esperam-se avanços nas ações escolares para construir e vivenciar uma nova narrativa contextualizada e significativa ao aluno, contribuindo, também, com a forma de ensinar e aprender dos diferentes professores, propiciando a estes uma ferramenta que possui embasamento científico, epistemológico e social.

Palavras-chave: Ensino de Química; Livro Paradidático; Proposta de ensino.

\section{INTRODUCTION}

Considering that Chemistry is the science whose purpose is to analyze and understand the matter, as well as the aspects related to its properties, constitution, transformations and energy involved in these processes, the National Curricular Common Base (Brazil, 2018), in relation to Sciences of Nature, reiterates that the conceptual knowledge associated with Chemistry is characterized as a source that allows the student to analyze, investigate and discuss certain problems. Thus, students are able to develop context-aware knowledge and recognize the limitations and potentialities of the natural sciences through activities that mobilize skills and maximize ability. However, understanding the chemical science in its fullness, as well as following the constant advances and discoveries, has been characterized as an arduous and complex task.

Otherwise, the importance of the relationship between the scientific content and the sociocultural context of the student, with emphasis on his ethical formation and the development of the intellectual autonomy and the critical thinking, in order that this one can exercise its citizenship based on the theoretical contributions and procedural aspects of the sciences, which is based on the National Curricular Parameters for High School (Brazil, 2000), in the Curriculum Guidelines for High School (Brazil, 2006) and in the National Curricular Common Base (Brazil, 2018). These, in turn, refer to documents that establish a set of essential learning for the promotion of an integral education, directed to the recognition and the full development of the students, with respect to the differences and confrontation to the discrimination and preconception (Brazil, 2018).

After all, according to Bedin and Del Pino (2019, p.7), "the student must seek information, construct ideas, exchange experiences and mobilize his/her competences to acquire theoretical-practical knowledge". For this action, the authors understand that the teacher "has the role of enabling the student to build cognitive structures of formation in a more significant perspective in the light of learning, giving the right to questioning and thinking about reality in the spaces where it is produced" (Bedin \& Del Pino, 2019, p.7).

In this sense, in order to foster pedagogical practice, directing the action of the teacher as a mediator of learning, it is suggest the use of didactic resources, among them the paradidactic book, which does not replace the didactic book, but complements it 
to the extent that contemplates theoretical and scientific contributions from a different perspective. After all, the paradidactic books are "materials very efficient from a pedagogical point of view, because they use aspects more playful than didactic books" (Torres, 2012, p.30), which means stimulating students to read, instigating curiosity and facilitating their understanding of a certain content, since they approach the contents studied in a more contextualized way, referring the theme to the student's reality.

Paradidactic books emerge in addition to contributing and encouraging the student to the specific study, as they appear as a differentiated form for the teacher contextualize and update the concepts and contents of the curricular component in a playful and meaningful learning bias. In particular, in Chemistry studies, this contextualization with other contents and the relation with the reality of the subject allows a greater interaction between the teacher and the student, intensifying the understanding of the phenomena that occur in their daily life. Thus, through the paradidactic books, the subjects are able to propose improvements for the local community, constructing and reconstructing ideas and ways to help themselves scientifically.

In this sense, it is seen that the paradidactic books are didactic tools that add pertinent and contextualized information to the teaching and learning processes through differentiated actions, such as playful and colloquial reading. In this sense, the paradidactic book becomes a tool of great potential in the teaching planning and in the elaboration of projects that aim at the qualification of the formation of the subject. After all, through the paradidactic book, the student is stimulated to enrich his practices of reading, since it presents a varied collection of content that allows him to understand the natural phenomena.

Moreover, the paradidactic book is expressive enough to make the teacher establish interdisciplinary relationships, seeking subsidies to heal the students' doubts and improve their didactic-pedagogical knowledge. In this contribution, the present article aims to reflect on an investigation carried out with teachers in initial formation in Chemistry in the light of the paradidactic books. Basically, it was sought to investigate and reflect on the teaching conceptions in relation to the questions: how useful is the paradidactic book? How to use the book in the classroom without disassociating with the scientific content? What is the potential of the paradidactic book engaged in teaching practice and student context?

This work becomes important in that it is understood that the paradidactic books are relevant for the formation of the subject, contemplating the organization of ideas, the maximization of knowledge and the construction of an argumentative, critical and reflexive identity, since, for through a healthy and enjoyable reading, one can benefit the formation of the student in real time and integrated to the knowledge of the teacher. Moreover, it is a way of promoting the teaching of chemistry in an investigative methodology, qualifying the teaching process and the roles of the subjects in the classroom, providing the student with a satisfactory learning. After all, using the paradidactic books is a methodology that "can be used as a guided process that leads the learner to situations capable of arousing the need and pleasure for the discovery of knowledge" (Bedin, 2019, p.102). 


\section{THEORETICAL REFERENCE}

The paradidactic books, according to Souza (2013), consist of thematic books that have the purpose of contributing to the qualification of the teaching and learning processes, as they are configured as a teaching tool through multiple activities, including play activities. This educational tool, according to Laguna (2001), corroborates the students' literary enrichment, due to their different language and format, which arouse the student's interest and curiosity insofar as they contemplate the object of study in a contextualized way.

Among the main characteristics of the books, it is observed that they generally do not meet an explicit sequence of concepts and contents, being essentially used as complementary materials to the teaching planning and the development of the teaching environment. Therefore, they do not consent to the fragmentation of a didactic book, but, on the contrary, they present a conducive disposition to contextualization and interdisciplinarity.

According to studies by Souza (2013), it has:

The paradidactic books appear as a complementation and not as a replacement of the didactic book. It provides the development of a study based on the historical, social and cultural aspects that circulate the subject under study, causing both the student and the teacher to explore a reality that is often unknown. (Souza, 2013, p.3)

Another aspect evidenced about the paradidactic books is found in the researches of Beneti (2008). Especially the researches point to the format and the body of the text, since they do not present a formal scientific approach, since they opt for an informal and relaxed exposition. Thus, through an accessible and often contextualized scientific language present in the paradidactic books, one can evidence the sciences in everyday life, as well as means to understand it as an element of its context, be it in the social, political, , economic or technological; this new perception about science can potentially contribute significantly to the understanding of content presented from a formal teaching perspective (Salém \& Kawamura, 1996).

According to Gomes (2009), to use the paradidactic book as a subsidy in the approach of a certain theme, before or during the teaching process, allows the integration of the scientific concepts to the subjects of the student's daily life, corroborating to the amplification of their perception's world. Thus, it is emphasized the obligation of its use to be linked to questions pertinent to the student's reality, correlating it to other areas of knowledge and portraying its object through a trivial language (Dante, 2010).

The planning of classes, based on the use of a paradidactic book, requires commitment in relation to the development of the teaching and learning processes of the teacher and of the students, since they contemplate the research practice of the development of the object of study, being conclusive the dedication of both during the realization (Skovsmose, 
2000). The use of this resource in a classroom encompasses a number of possibilities, either as a subsidy to its beginning, as a means of contextualizing a homework content or as a research complement, characterizing its use of free application (Dante, 2010), since the use of the paradidactic book provides to the student the revision of concepts, allowing its construction and reconstruction of the meanings from new perceptions in a wide and ludic approach (Boaventura, 2016).

In this perspective, Rondow Junior e Oliveira (2009) emphasize that the flexibility and the elaboration of the paradidactic book are characterized as instruments that potentiate the process of knowledge construction, because when well-written the paradidactic book integrates the pedagogical proposals used for the development of the content, promoting the student's active and critical participation through questioning and discussion. After all, as well as constituting itself as a concrete tool, it has a symbolic character as a result of the adequacy of the language, configuring itself in a simple language to approach its real objective, which refers to the connection of scientific knowledge to reality of the student.

By the very nature of the paradidactic text, its author can enjoy a certain freedom in its production, not being rigidly tied to curricular proposals with a certain sequence. The subjects addressed should meet the educational objectives related to the skills and competences to be achieved by the students. The author may opt for a more informative or more critical text, loaded with his points of view; may choose to follow a historical sequence or for comings and goings within the history and, finally, will have freedom in the choice of the problematic to be approached. (Rondow Junior \& Oliveira, 2013, p.9)

As mentioned above, paradidactic books do not have the obligation to meet the requirements of a didactic book, because unlike this, paradidactic books do not have a regulatory body. Because of this, its body of text does not present a rigid formatting, either in aspects like elaboration and / or development of the knowledge, corroborating to the potentiality of this instrument of education in any level of schooling. The author Munakata (1997), besides affirming that the paradidactic books come from the national creation, reflects that there is a representation of this genre in other nationalities, which do not meet the same nomenclature.

Boaventura (2016) points out that the use of the paradidactic book as a pedagogical resource should consider a line of coherence between the objectives drawn as a result of the object of study and the objectives related to the indication of the respective reading. In this way, one of the main positive aspects of the use of this one is evidenced: the incentive to the autonomy and criticality of the student, through the contextualization of the concepts and contents.

In this sense, the paradidactic book, among the skills and abilities of the teacher, is able to relate the scientific content to the context of the student, which transcends from 
a mere spectator role to an active participant in the process of knowledge construction (Gonçalves Pinto, 2013); the teacher, in turn, acts as mediator of this process (Dal Pupo, 2015), characterizing itself as a basic premise so that the teaching and learning processes can occur in a satisfactory way. In collaboration, Bedin (2019, p.102) states that "the work of the chemistry teacher should not be limited to transmitting contents and meanings of symbols and formulas, but favoring the psycho-cognitive activities of students, making them become important characters in the assimilation and resignification of concepts".

Thus, the educator is responsible for the planning of the proposals that involve the use of the paradidactic books, which should be centered on the students and contemplate strategies that provide the interaction of practical and theoretical aspects of the object under study, so that they take ownership of theories and concepts of the natural sciences, corroborating for the emergence of hidden capacities, development of autonomy, improvement of the capacity of decision making and analysis, evaluation and resolution of problems (Munford \& Lima, 2007; Carvalho, 2013).

In this sense, it should be emphasized that when preparing this didactic resource for use in class, one should contemplate the general objective, which should be directly related to the knowledge that is intended to potentiate, considering the previous knowledge of the student. In this sense, the paradidactic book has the purpose of making possible the access both to scientific knowledge and the information necessary to live in society, either through readings representative of its reality, cherishing the appropriation of these knowledge, either through dialogue or discussion in the classroom. In addition, the use of the paradidactic book in the classroom is extremely important, especially in the learning environments of the Exact Sciences, since, through the contextualization of the object of study and interdisciplinarity, this resource allows the maximization of the teaching process, fostering the concretization of knowledge and modeling, commonly overlooked in didactic books (Araujo, 2018).

Based on the assumptions presented, it is understood that the use of paradidactic books as a didactic alternative in the teaching of science corroborates for the qualification of teaching and learning processes, as well as for the improvement of teaching and the mobilization of skills, abilities and student attitudes. After all, the use of this resource stimulates the student to develop knowledge in a unique and interdisciplinary way, allowing the integration of different areas of knowledge through exchanges, discussions and reflections on content (Precioso \& Salomão, 2014).

\section{METHODOLOGY}

The results presented in this work come from a qualitative and investigative research, considering as a starting point the conceptions and perceptions of Chemistry pre-service teachers about the use and pedagogical validation of the paradidactic books in Chemistry Teaching. The research was developed with 9 pre-service teachers in Chemistry 
during a class of Supervised Curricular Internship II, of a community university in the metropolitan region of Porto Alegre, because in this discipline, one of the pillars that support it is directed to reading, analysis and discussion on texts of articles and books that encompass the theme.

From this point of view, the discipline of Internship II is divided in two moments referring to the paradidactic books; the 1st moment: previous reading of scientific articles about paradidactic books provided by the teacher for classroom socialization; and the 2nd moment: intense reading on a paradidactic book for presentation, with emphasis on questions regarding the use, learning mechanisms and didactic strategies and discussion in the classroom.

Thus, after the students have read and interpreted the scientific articles that reflect on the use and importance of the paradidactic book in the classroom (1st moment), the teacher of the discipline, to start the critical discussion and the constructive debate on the subject, considering the construction of knowledge for the second moment, applied a questionnaire to the students.

This questionnaire, as an empirical part of this article, was analyzed in the light of Bardin's Content Analysis (2011), and its qualitative and quantitative data are expressed through figures and tables. It should be noted that the questionnaire was used as a way of instigating students to the initial debate, since, as Gil (1999, p.128) argues, the questionnaire is used as a method of understanding “opinions, beliefs, expectations, lived situations etc." of the pre-service teachers.

For the decoding of the data present in this questionnaire, as mentioned above, use was made of Content Analysis, since this is:

[...] a set of communication analysis techniques aimed at obtaining, through systematic and objective procedures for describing the content of the messages, indicators (quantitative or otherwise) that allow the inference of knowledge regarding the conditions of production/reception of these messages. (Bardin, 2011, p.47)

Otherwise, Bardin (2009) affirms that Content Analysis is a technique that seeks to analyze subjects' placements through systematic procedures and objective description of message content. To this end, it employs an organization around three phases; the pre-analysis (reading the scriptures for analysis), the exploration of the material (elaboration of compilation units with techniques of decoding, classification and categorization) and the treatment of the results (categories and explanations about the scriptures).

Thus, we have that the research is drawn in a qualitative bias that, according to Araújo, Oliveira e Rossato (2017 apud Scheunemann et al., 2018, p.26), "it is characterized 
as a process of understanding and interpretation, and not just with the simple explanation of realities." That is, it seeks to immanently understand the conception of individuals about paradidactic books, emphasizing the specific and interactionist processes of these subjects in the form of data analysis and interpretation.

\section{ANALYSIS, RESULTS AND DISCUSSION}

Based on the analysis of the data concerning the personal information of the collaborators of this research, a profile of those involved was traced and it was found that $90 \%$ are female and $10 \%$ male. They are in the age range of 22 to 36 years, with only $10 \%$ working in the public-school system. Moreover, as in a legitimate methodological process, attention is paid to the limitations of the work in terms of the representativeness of the answers, which, even if they refer to this group of teachers in formation and, therefore, have validity when talking about this group, are not widely generalizable. Therefore, the interpretations and reflections exposed below are exclusive to the group of teachers who acted as respondent of the activity.

Still, it is noteworthy that all the tables below, which present excreta referring to the conception of the subjects, are illustrative in the sense of representing some answers of these, not limited to the large group. However, the Content Analysis, shown in the figures, extends the totality of the respondents, not weakening or generalizing their statements. In addition, it should also be noted that the answers are not extensive and related to the same representative subject in all tables. That is, in table 1 , the answer 1 is not from the same subject as presented in table 2 with answer 1; These are randomly selected responses to represent the conceptions of the subjects.

Based on the analyzes carried out on the question "What do you understand by a paradidactic book?", it was verified that in the majority the subjects met the expectations in the light of the theoreticians, as specified in Table 1. That is, in connivance with Boaventura (2016), the pre-service teachers understand the paradidactic book as a material of its own characteristics, mainly related to its colloquial language and its interdisciplinary character, being commonly used as complementary material for consultation and research, both by teachers and students.

Table 1

Excerpts concerning the question $1 .^{1}$

Answer 1 Paradidactic books are books that help and complement the teacher's study that can also serve as a source for student research. As they are related to other areas of knowledge, they approach interdisciplinarity, thus achieving significant knowledge for the student. They have different characteristics from textbooks, for example, they do not follow a pattern of content.

\footnotetext{
${ }^{1}$ The placements in the table are identical to those presented by the subjects in the questionnaire; therefore, the writings of the same were not translated or organized, in order to demarcate the essence of their positions. Likewise, it is emphasized that only a portion of the issues are presented in the table, by virtue of their representative character.
} 
Answer 2 A paradidactic book is one that brings along the context of a particular subject, in order to facilitate the student's understanding of a particular content, with a more accessible language, to favor the process of teaching and learning of the reader.

Answer 3 Paradidactic books are books that study a certain content in a more playful and contextualized way, bringing the contents to be addressed to the reality of each student.

Answer 4 It is a book that is not used as a didactic, assists in the teaching-learning process and works as a complementary material to make the classes more dynamic.

Answer 5 Complementary books to textbooks, so that students have better knowledge, better develop interpretation, improve vocabulary, stimulate logical thinking, and make the student imagine, know and delve into new worlds, new stories and knowledge.

From the Bardin's Content Analysis (2011), carried out on this question, it is noticed that the subjects, in categories, understand the paradidactic book as a way to favor the student learning, not exposing concepts and content in a traditional way. That is, the book is not responsible for technical content, which ends up qualifying the teaching planning, because it presents itself a playful and contextualized tool capable of intensifying learning. From the categories, it was plotted the Graph 1 that shows in detail the percentage of each one.

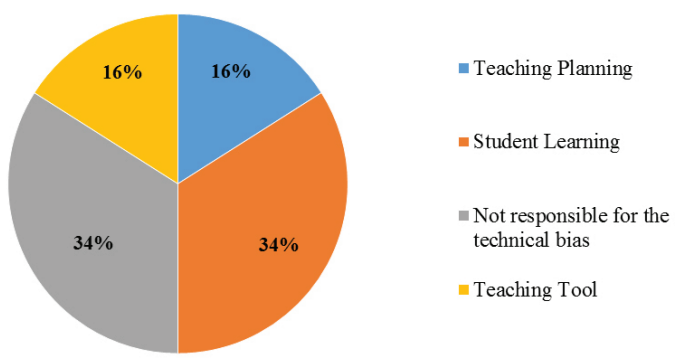

Graph 1. Emerging categories of the question: What do you understand by a paradidactic book?

Table 2 presents the conceptions of the pre-service teachers on the questioning: "For you, what is a paradidactic book?". In the interpretation of these, it is possible to perceive, as for Laguna (2001), that the pre-service teachers emphasize the use of the paradidactic book as a mean to foment the pleasure by reading and to qualify the environment of the classroom, establishing coherence between the pedagogic objectives resulting of the approach of a certain content with the reading of the paradidactic book, being characterized as a pedagogical tool of great potential for the construction of the knowledge of significant form.

Table 2

Excerpts relating to question 2. 
Answer 1 The paradidactic book serves to help work classroom topics in an interdisciplinary way, where this form of teaching brings the pursuit of the most meaningful knowledge to the student. The paradidactic book does not bring this form of teaching, and becomes insufficient for certain subjects worked in the classroom. The paradidactic book has the function of complementing the didactic book, not replacing it. Encourages reading in the classroom, makes the student have a better interpretation of the contents to be worked, because they are books with a simpler reading, where the student has a better ease and willingness to learn.

Answer 2 To contextualize and assist the teaching process of the student, bringing to him an easier way to learn, also assists the intellectual development of the student.

Answer 3 I believe that the use of the paradidactic book is necessary, because it presents transversal themes that enrich the teaching and learning process, which are not deepened in the didactic books.

Answer $4 \quad[. .$.$] It serves to make a more playful and enjoyable reading, bringing discussions about facts that$ often happen in our daily lives. The paradidactic book is a more relational mode of study in which knowledge can be constructed in a more interactive way.

Answer 5 It serves as a pedagogical tool that assists both students and teacher in the teaching-learning process.

When analyzing the emergent categories for the second problematization, we can see that these, for the most part, as shown in figure 2, conceive the paradidactic book as a study complement to the teacher, because it is a differentiated way of planning his classes without a bias, aesthetically, scientific. Still, they outline the ideas of an auxiliary tool for teacher planning and means of enhancing student learning by encouraging reading, interpretation and decoding of ideas, symbols and information.

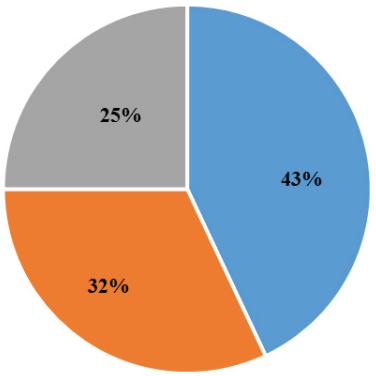

- Complement study

- Planning Assistant

- Learning Potentializer

Graph 2. Emergent categories of the question: What is a paradidactic book for?

When asked about the use of the paradidactic book to work a content in the Teaching of Chemistry (Table 3), pointing it in detail, the pre-service teachers, according to Rondow Júnior and Oliveira (2009), emphasize that the use of this resource makes the access to contextualized information, corroborating the conduct of debates and discussions, which, according to the aforementioned authors, would not exist due to the limitation to the use of the didactic book.

The categories that emerged in the placement of the pre-service teachers present an idea of context significance in the light of the paradidactic books, either through projects 
(30\%), extra class activities (30\%), contextualized actions $(20 \%)$ or practical actions $(20 \%)$. The important thing, in the opinion of these pre-service teachers, is to link the student's reality to actions that do not maximize only the scientific knowledge of the classroom, but in processes that glimpse the action of the subject as the personal, social and cultural protagonist of the being itself.

Table 3

Excerpts relating to question 3.

\begin{tabular}{|c|c|}
\hline Answer 1 & $\begin{array}{l}\text { I would use it to develop project works, making debates about the subject of the book, can be } \\
\text { working in conjunction with other disciplines, and putting into practice interdisciplinarity. }\end{array}$ \\
\hline Answer 2 & $\begin{array}{l}\text { The paradidactic book could be used in parallel with a certain content that is being worked in the } \\
\text { classroom, in order to understand its context, or, in order to propose activities with it, correlating } \\
\text { content and/or disciplines. }\end{array}$ \\
\hline Answer 3 & $\begin{array}{l}\text { I would choose a themed book that is aligned with content that has a little to do with school reality } \\
\text { and would do work, summary, debate. }\end{array}$ \\
\hline Answer 4 & $\begin{array}{l}\text { In proposals for practical activities, where the student would be required to apply the knowledge } \\
\text { acquired. }\end{array}$ \\
\hline Answer 5 & $\begin{array}{l}\text { I would use the paradidactic book as a support for developing discussions about the chemistry } \\
\text { discipline. }\end{array}$ \\
\hline
\end{tabular}

Regarding the questioning: "In your pedagogical practice, how would you use the paradidactic book to develop a content of Chemistry in an interdisciplinary way?" the majority of the pre-service teachers expose interesting and particular ideas, as shown in Table 4. It is emphasized, as pointed out by Souza (2013), that the use of paradidactic books gives students the possibility of exploring an unprecedented reality, a fact that is easily evident in the commentary of a pre-service teachers in that it proposes a study on the interference of soil $\mathrm{pH}$ in certain foods, for example.

Table 4

Excerpts relating to question 4.

\footnotetext{
Answer 1 The paradidactic book could be used to correlate the disciplines of history and chemistry, such as metal bonds, in order to contextualize with the age of metals, where the first evidence of chemical bonds, such as amalgam, arose.

Answer 2 To work in an interdisciplinary way, it is necessary to have a common goal, for example, to study the cause of corrosion of metal surfaces in coastal regions, bringing a paradidactic book that encompasses this theme, it is possible to correlate chemistry, biology, physics and mathematics.
} 
Answer 3 I would work on a particular theme, for example $\mathrm{pH}$. Thus would develop a work relating the other subjects with the proposed theme. In chemistry, what is the $\mathrm{pH}$, its scale, its characters: acid, basic or neutral? In the field of biology, how soil and water $\mathrm{pH}$ interfere with food production, agriculture, aquatic living, and how this $\mathrm{pH}$ changes occur in the environment?

Answer 4 It would use as another didactic resource in the teaching-learning process, introducing concepts and contents necessary for the student to understand the chemical processes and relate them to issues involving social, technological, economic and political aspects, preparing them to actively participate in a social and environmental society.

Answer 5 I would choose a subject that could work in an interdisciplinary way and use the book as a source for consultation and analysis. For example, a book that talks about pesticides could be worked in an interdisciplinary way with the biology discipline, for example, by looking at what happens in nature, in the environment, in humans.

Especially on the interdisciplinary question in the light of the paradidactic books, through the Content Analysis of Bardin (2011), the emergence of the categories referring to the contexts of development of activities: scientific means (30\%), cultural environment $(30 \%)$ and social environment (40\%). Although the excerpts quickly demonstrate the ideas of the pre-service teachers in working in an interdisciplinary way, it is possible to perceive that they point the paradidactic book as a tool of support to the research and the extension of activities that, as demonstrated in the previous question, are intertwined in projects of research and extra-class activities.

Table 5 shows the responses of the pre-service teachers in relation to the question: "What were the benefits gained by reading about the article about the paradidactic book?". From the subjects' placements, the potentiality of the developed activity is verified, since it gave a significant way to the understanding about the use of paradidactic books as pedagogical proposal. As a way to exemplify the subsidies of this statement, you can highlight the students' comments about the questioning.

Table 5

Excerpts referring to question 5.

Answer 1 The article had an easy interpretation, being a pleasant and thought-provoking reading. I knew little about the subject, and it is always important to know that there are other resources to be worked on in the classroom, as it makes the teacher have other ways to work interdisciplinarity, developing different methodologies thus obtaining a more productive, differentiated and meaningful class, for both the teacher and the student. 
Answer 2 After reading, it was verified how important is the paradidactic book, as it serves as a complement to the teaching and learning process, not only of the student, but also for the teacher, being this an accessible and contextualized language book.

Answer 3 To know more about this subject, since I had never had contact with paradidactic books before. It enriched my options on how to work new content with students.

Answer 4 Greater knowledge of what paradidactic books are, and what they are for. Importance of paradidactic books for the learning of both students and teachers.

Answer 5 To be able to differentiate a didactic from a paradidactic book and become aware of this supporting tool

From the understanding of the subjects' positions and the Content Analysis, the categories exposed in Graphic 3 were identified. In it, it is possible to identify with greater intensity that the pre-service teachers expose the idea of constructing new ideas and of knowing this didactic resource, as well how to develop knowledge about the book and constitute a new work option. Moreover, some pre-service teachers state that they did not know the tool, enabling a new way of constructing didactic and methodological knowledge to qualify teaching, since they had to think, reflect and act on knowledge in the light of the constructed paradidactic books.

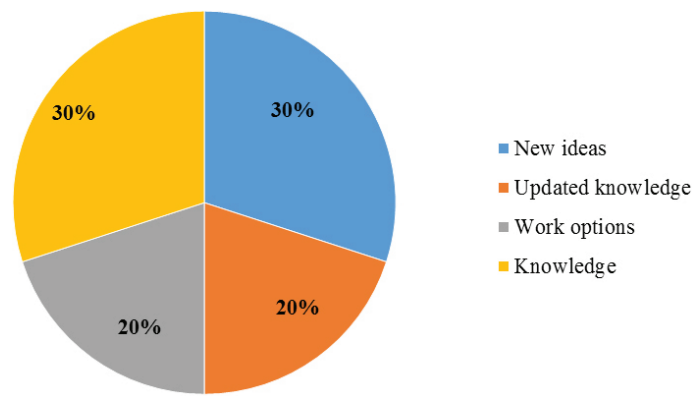

Graph 3. Emerging categories of the question about the benefits acquired throughout the activity.

Finally, the last part of the questionnaire, represented by figure 4, contemplates a series of questions that were answered by the pre-service teachers according to the Likert scale. These scales, also known as summed scales, "require respondents to indicate their degree of agreement or disagreement with statements about the attitude being measured" (Brandalise, 2005, p.4). In the chart below, it should be noted that, by aesthetic measure, the affirmations were placed as legend, characterizing them as A, B, C, D, E, F, G, H, $\mathrm{I}$, and $\mathrm{J}$.

Thus, as it is possible to observe in affirmative A, the pre-service teachers confirm a significant appropriation about the developed theme, possessing the necessary skills and abilities to incorporate this pedagogical resource into their teaching practice, considering their fundamental peculiarities, such as language 
and contextualization. This conception of knowledge appropriation about the paradidactic book is important in the initial formation of teachers, since it supports the qualification of the teaching process, behaving as the link between student, content and context that characterizes the classroom as an effective space for exchanges, debates and discussions.

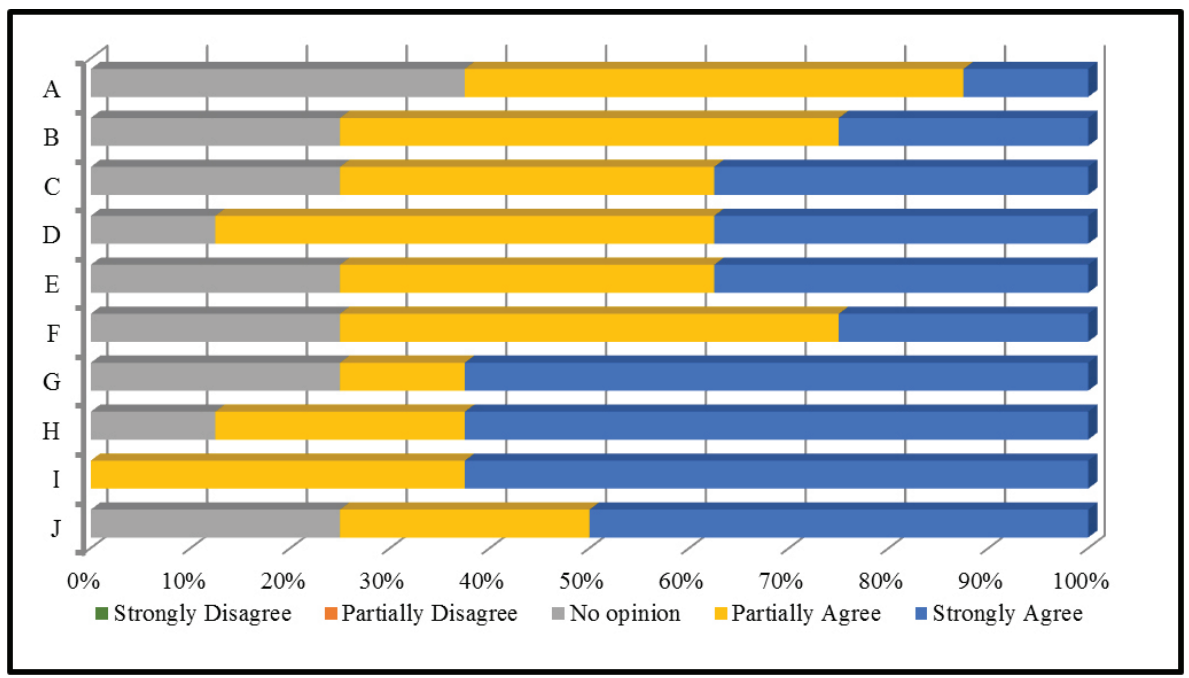

Caption: (A) I have sufficient knowledge about paradidactic books. (B) I can think about how to work a chemical content with a paradidactic book. (C) By correlating the chemistry content to a paradidactic book, I am able to create challenging tasks for my students. (D) By correlating the chemistry content to a paradidactic book, I can help my student in his or her learning. (E) By correlating the chemistry content to a paradidactic book, I am able to help my student reflect on his or her learning. $(F)$ By correlating the chemistry content to a paradidactic book, I am able to instigate my students to critical discussion. (G) By correlating the chemistry content to a paradidactic book, I am able to identify my difficulties in the chemistry contents. $(\mathrm{H})$ By correlating the chemistry content to a paradidactic book, I mobilize different knowledges that make me even more a teacher. (I) By correlating the chemistry content to a paradidactic book, I can instigate myself to learning. (J) By correlating the content of chemistry to a paradidactic book, I mobilize my skills and abilities in chemistry.

Graph 4. Percentage of agreement of the pre-service teachers in relation to the assertions.

Still in relation to the analyzes of the statements presented in graph 4, in relation to the assertions $\mathrm{B}$ and $\mathrm{C}$, which depict the position of the pre-service teachers against the use of this didactic resource, in order to promote challenging spaces for their students, they perceive, in their favorable answers, partially or totally agreeing with the statement. Therefore, according to the perception of the pre-service teachers, the paradidactic book consists of a good didactic resource, that contributes to the amplification and construction of the knowledge of significant form. Boaventura (2016) contends that, unlike the didactic book, the paradidactic does not have a rigid structure, providing greater autonomy for teachers and students regarding its use.

In reference to the statements $\mathrm{D}, \mathrm{E}$ and $\mathrm{F}$, which point out the use of the paradidactic book as an instrument capable of assisting in the teaching and learning processes, promoting spaces for reflection and critical discussion, the pre-service 
teachers position themselves as follows: of $37,5 \%$ to $50 \%$ partially favorable and from $25 \%$ to $37,5 \%$ fully agree with the statement, the rest stated that they do not know how to comment on the questioning. From these considerations, it is noticed that the academics recognize their limitations regarding the use of this pedagogical tool, since it is directly linked to the interdisciplinarity, which requires of the teacher, besides the scientific knowledge, experiences that encompass both an accurate view of the social context, and the relationships that are formed in this environment.

As for the assertions $\mathrm{G}, \mathrm{H}, \mathrm{I}$ and $\mathrm{J}$, these are correlated between the use of the paradidactic book and teacher training, in aspects such as: difficulties pertinent to scientific knowledge and teaching knowledge that emerge in pedagogical practice. In these, a percentage between $50 \%$ and $62.5 \%$ fully agree with the statements, $25 \%$ to $37.5 \%$ agree partially, while the rest had nothing to declare. In this sense, there is evidence of an engagement regarding the use of this resource, due to its potential as a pedagogical instrument in the teaching and learning processes, both for teachers and students. In a similar way, this tool, according to Teixeira (2009), assists teachers in the mediation aspects of the knowledge historically instituted by society, helping in the understanding of this knowledge, as well as in the reflection and critical discussion about them.

From this perspective, from the analysis of the applied questionnaire and the emergence of the categories based on Bardin (2011), it is noticeable the importance of the use of this resource in pedagogical practices, corroborating with the teaching and learning processes, with the improvement of teaching and learning., mainly with the contextualization of scientific knowledge in the light of the student's sociocultural knowledge, mediating the teaching of multiple forms from environments conducive to the construction of autonomy and critical argumentation in the subject. After all, as a standout, the paradidactic book promotes the student's approach with its respective object of study in the light of an informal language.

\section{CONCLUSION}

In view of the above, it can be said that the paradidactic books modify the teaching didactic posture, because by means of the use of these a creative, provocative and daring teacher is constituted. An educator who provides quality work in the school environment from the paradidactic book enables the student to understand chemistry in a way different from that presented in the didactic book. That is, the paradidactic book is an important pedagogical resource because, besides presenting a non-formal scientific language, which intensifies the way the student read and understand the world, maximizes activities and corroborates for the (re) construction of knowledge, being the planning a fundamental step in this process. 
Based on the considerations presented by the chemistry pre-service teachers, it is stated that the paradidactic book is an instrument capable of assisting in the development of teaching and learning processes, since it promotes moments of reflection and critical discussion. The pre-service teachers consider the paradidactic book a good didactic resource, since it contributes to the construction of the knowledge in a significant and contextualized way. Yet, they recognize their difficulties regarding the relationship between work with the book in an interdisciplinary way, from which they go beyond specific knowledge.

In this drawing, it is believed that activities related to the paradidactic book should be approached more frequently in the initial formation of teachers, so that they can achieve different knowledge regarding this tool. In this sense, what is expected of the teachers of this new millennium is not the abandonment of what has already been built in education, but the improvement and qualification of all their virtues and duties with knowledge. The teacher has the mission to encourage the new and awaken pertinent questions to the student. In addition, through the authors who based this text, it is possible to understand how valid is the use of books for the initial formation of teachers for the integration and appropriation of content to the reality of Basic Education students.

Finally, it is recognized that this practice requires the commitment of teachers through the planning of classes and mainly reflections of this practice in the initial teacher training. Thus, it is emphasized that the paradidactic book cannot be seen as a salvation the difficulties encountered daily in the classroom, but as a way to enable new discussions about how to teach and learn in Basic Education. Therefore, considering that it is necessary to think about progress in school actions in order to construct and experience a new contextualized and meaningful narrative to the student, it is expected that this research contributes to the way of teaching and learning of the different teachers, providing them with a tool which, in fact, has a scientific, epistemological and social basis to instigate the autonomous learning of the student and the improvement of the teaching practice.

\section{AUTHOR CONTRIBUTION STATEMENT}

This article was prepared and organized by the three authors. The Introduction and Conclusion were initially developed by L.P. The Theoretical Framework and Analysis, Results and Discussion were prepared by D.L.K. The methodology and organization of the final text were left to E.B. At the end, all authors reread the text and contributed to its final version. 


\section{DATA AVAILABILITY STATEMENT}

Data supporting the results of this study will be made available by the corresponding author, D.L.K., upon reasonable request.

\section{REFERENCES}

Araujo, R. F. G. (2018). A utilização de material paradidático no ensino de conceitos iniciais de óptica geométrica (92f.). Dissertação de Mestrado, Universidade de Brasília, Brasília.

Bardin, L. (2009). Análise de Conteúdo. Tradução de Luís A. Reto e Augusto Pinheiro. 5ed. Lisboa: Edições 70.

Bardin, L. (2011). Análise de conteúdo. São Paulo: Edições 70.

Bedin, E. \& Del Pino, J. C. (2019). DICUMBA: uma proposta metodológica de ensino a partir da pesquisa em sala de aula. Ensaio Pesquisa em Educação em Ciências, (21), 1-22. Recuperado em 15 maio, 2019, de http://dx.doi.org/10.1590/1983-21172019210103

Bedin, E. (2019). Filme, Experiência e Tecnologia no Ensino de Ciências Química: uma sequência didática. Revista de Educação, Ciências e Matemática, 9(1), 101-115. Recuperado em 30 jul, 2019, de http://publicacoes.unigranrio.edu.br/index.php/recm/ article/view/4280/2882

Beneti, A. C. (2008). Textos paradidáticos e o ensino de física: uma análise das ações do professor no âmbito da sala de aula (138f.). Dissertação de Mestrado, Universidade Estadual Paulista, Bauru.

Boaventura, K. J. (2016). A História da Ciência como Objeto Mediador do Conhecimento do Conteúdo de Parasitologia no Ensino Médio: Um Livro Paradidático (282f.). Dissertação de Mestrado, Universidade Estadual de Goiás, Goiás.

Brandalise, L. T. \& Bertolini, G. R. F. (2013). Instrumentos de medição de percepção e comportamento - uma revisão. Rev. Ciênc. Empres. UNIPAR 14(1), 7-34. http://revistas. unipar.br/index.php/empresarial/article/view/4661

Brasil. (2000). Secretaria de Educação Média e Tecnológica. Parâmetros Curriculares Nacionais para o Ensino Médio - Ciências da Natureza, Matemática e suas Tecnologias. Brasília. MEC/SEF.

Brasil. (2006). Secretaria de Educação Média e Tecnológica. Orientações Curriculares para o Ensino Médio - ciências da Natureza, Matemática e suas Tecnologias. Brasília. $\mathrm{MEC} / \mathrm{SEF}$.

Brasil. (2018). Base Nacional Comum Curricular. Educação é a Base. Brasília, MEC/ CONSED/UNDIME. Recuperado em 17 maio, 2019, de http://basenacionalcomum.mec. gov.br/wp-content/uploads/2018/02/bncc-20dez-site.pdf.

Carvalho, A. M. P. (2013). O ensino de Ciências e a proposição de sequências de ensino investigativas. In A. M. P. Carvalho (org.). Ensino de Ciências por investigação: condições para implementação em sala de aula. São Paulo: Cengage Learning. 
Dal Pupo, D. (2015). Sua nova majestade a soja: um paradidático como estratégia pedagógica no ensino de Química em Mato Grosso (197f.). Dissertação de Mestrado, Universidade Federal do Mato Grosso, Cuiabá.

Dante, L. R. (2010). Matemática e suas aplicações. São Paulo: Ática.

Gil, A. C. (1999). Métodos e técnicas de pesquisa social. 5. ed. São Paulo: Atlas.

Gomes, D. C. L. (2009). Paradidático para quê? Repensando o uso desse material. Revista Eletrônica de Ciências da Educação, 8(2), 1-11. http://www.periodicosibepes.org.br/ index.php/reped/article/view/821.

Gonçalves Pinto, A. (2013). Uma proposta de livro paradidático como motivação para o ensino de Matemática. (56f.). Dissertação de Mestrado, Universidade Federal Rural do Rio de Janeiro, Rio de Janeiro.

Laguna, A. G. J. (2001). A contribuição do livro paradidático na formação do aluno leitor. Revista Acadêmica, (2), 43-52. Recuperado em 24 abril, 2019, de https://doi. org/10.22287/ag.v0i2.81.

Munakata, K. (1997). Produzindo livros didáticos e paradidáticos (223f.). Tese de Doutorado, Pontifícia Universidade Católica de São Paulo, São Paulo, Brasil.

Munford, D., \& Lima, M. E. C. D. C. (2007). Ensinar ciências por investigação: em quê estamos de acordo? Ensaio Pesquisa em Educação em Ciências, 9(1), 89-111. http:// dx.doi.org/10.1590/1983-21172007090107.

Rondow Júnior, N., \& Oliveira, L. M. L. P. (2009). O ensino da termodinâmica na perspectiva sociointeracionista: proposta de um livro paradidático. In: Anais do Encontro Nacional de Pesquisa em Educação em Ciências (pp.1-12). Florianópolis, Brasil. Recuperado em 09 abril, 2019, de http://posgrad.fae.ufmg.br/posgrad/viienpec/pdfs/838. pdf.

Salém, S., \& Kawamura, R. (1996). O texto de divulgação e o texto didático: conhecimentos diferentes? In: Anais do V Encontro de Pesquisadores de Ensino de Física (pp.588-598). Minas Gerais, Brasil.

Scheunemann, C. M. B., De Almeida, C. M. M., \& Lopes, P. T. C. (2019). Digital Technologies in the Teaching and Learning of Human Anatomy: analysis of the perceptions of Higher Education academics. Acta Scientiae, 21(1), 20-38. Recuperado em 10 maio, 2019, de https://doi.org/10.17648/acta.scientiae.v21iss1id4798.

Skovsmose, O. (2000). Cenários para investigação. Bolema (14), 66-91. Recuperado em 15 abril, 2019, de http://www.pucrs.br/ciencias/viali/tic literatura/metodologia/ Skovsmose Cenarios Invest.pdf.

Souza, J. P. (2013). Uma introdução dos livros paradidáticos no ensino de Matemática. In: Anais do VI Congresso Internacional de Ensino de Matemática (pp.1-13). Canoas, Brasil. Recuperado em 13 maio, 2019, de http://posgrad.fae.ufmg.br/posgrad/viienpec/ pdfs/838.pdf.

Teixeira, R. (2009). A representação social do negro no livro didático de história e língua portuguesa. In: Anais do IX Congresso Nacional de Educação (pp.392-402). Pernambuco, Brasil. Recuperado em 15 de abril, 2019, de https://educere.bruc.com.br/ arquivo/pdf2009/2079 1091.pdf. 
Torres, L. (2012). O livro paradidático como ferramenta para o Ensino da Educação Ambiental (74f.). Dissertação de Mestrado, Americana: Centro Universitário Salesiano de São Paulo, São Paulo. 